\title{
EFEK EKSTRAK DAN FRAKSI DAUN SALUNG (Psychotria viridiflora) Reinw. ex. Blume PADA SEL KANKER SERVIKS HeLa
}

\author{
Arlina Ismaryani \\ Akademi Kebidanan Persada Palembang
}

Informasi Artikel :

Diterima : April 2018

Disetujui : Mei 2018

Dipublikasikan : Juni 2018

*Korespondensi Penulis :

Arlina401@gmail.com

\section{A B S T R A K}

Menurut World Health Organization (WHO), kanker serviks menduduki urutan kedua dari penyakit kanker yang menyerang perempuan di dunia dan urutan pertama untuk wanita di negara berkembang. Etiologi utama kanker serviks adalah infeksi persisten virus Human Papilloma Virus $(H P V)$. Tumbuhan Salung telah dimanfaatkan secara turun temurun untuk mengobati berbagai macam penyakit. Tujuan penelitian untuk mengetahui efek ekstrak dan fraksi daun salung (Psychotria viridiflora Reinw. Ex. Blume) sebagai antiproliferasi dan penginduksi apoptosis pada sel kanker serviks HeLa. Penelitian ini termasuk penelitian eksperimen dengan desain penelitian post test only control design. Subjek pada penelitian ini adalah kultur sel HeLa. Konsentrasi ekstrak dan fraksi n-heksan, fraksi etil asetat, fraksi methanol air menggunakan konsentrasi 640; 320; 160; 80; 40 $\mu \mathrm{g} / \mathrm{ml}$, sedangkan cisplatin menggunakan konsentrasi $200 ; 100 ; 50 ; 25$ $\mu \mathrm{g} / \mathrm{ml}$. Hasil penelitian didapatkan nilai $\mathrm{IC}_{50}$ ekstrak 380,7 $\mu \mathrm{g} / \mathrm{ml}$, fraksi nheksan sebesar 229,3 $\mu \mathrm{g} / \mathrm{ml}$, fraksi etil asetat sebesar 116,8 $\mu \mathrm{g} / \mathrm{ml}$, dan fraksi methanol air sebesar 562,8 $\mu \mathrm{g} / \mathrm{ml}$, sehingga fraksi etil asetat mempunyai aktivitas sitotoksik kategori cukup aktif dilihat dari nilai $\mathrm{IC}_{50}$. Dapat disimpulkan bahwa ekstrak dan fraksi daun salung memiliki efek sitotoksik, berperan sebagai antiproliferasi dan penginduksi apoptosis pada sel kanker serviks HeLa.

Kata Kunci: Daun Salung, Ekstrak, Fraksi

\section{ABSTRACT}

According to the World Health Organization (WHO), cervical cancer ranks second of cancer that affects women in the world and the first order for women in developing countries the main etiology of cervical cancer is persistent infection of the virus Human Papilloma virus (HPV). Plant Salung have been used for generations to treat various diseases. The purpose of the study to determine the effects of leaf extracts and fractions salung (Psychotria viridiflora Reinw. Ex. Blume) as the anti-proliferation and inducer of apoptosis in HeLa cervical cancer cells. This research was experimental research design with post test only control design. Subjects in this study were HeLa cell. Concentration of extracts and n-hexane fractions, ethyl acetate fraction, the fraction of water using a methanol concentration of $640 ; 320 ; 160 ; 80 ; 40 \mu \mathrm{g} / \mathrm{ml}$, while cisplatin using a concentration of 200; 100; 50; $25 \mu \mathrm{g} / \mathrm{ml}$. The results showed $\mathrm{IC}_{50}$ extract value $380,7 \mu \mathrm{g} / \mathrm{ml}$. n-hexane fraction amounted to $229,3 \mu \mathrm{g} / \mathrm{ml}$. ethyl acetate fraction of $116,8 \mu \mathrm{g} / \mathrm{ml}$, and amounted to $562,8 \mu \mathrm{g} / \mathrm{ml}$ fraksimethanol water, so that the ethyl acetate fraction had enough categories active cytotoxic activity seen from the $I C_{50}$. It can be concluded that the extracts and fractions of leaves salung have a cytotoxic effect, acts as an anti-proliferation and inducer of apoptosis in HeLa cervical cancer cell.

Keywords: Leaf Salung, extracts, fraction 


\section{PENDAHULUAN}

Menurut World Health Organization (WHO), kanker serviks menduduki urutan kedua dari penyakit kanker yang menyerang perempuan di dunia dan urutan pertama untuk wanita di negara berkembang. Dari data badan kesehatan dunia diketahui terdapat 493.243 jiwa per tahun penderita kanker serviks baru di dunia dengan angka kematian karena kanker ini sebanyak 273.505 jiwa per tahun. Di Indonesia, terdapat 90-100 kasus kanker serviks per 100.000 penduduk. Kasus baru kanker serviks ditemukan 40-45 kasus per hari (Pitkin et al., 2003).

Etiologi utama kanker serviks adalah infeksi persisten virus Human Papilloma Virus (HPV). Infeksi dengan HPV mengakibatkan terjadinya integrasi genom DNA HPV dengan host sehingga terjadi gangguan atau hilangnya gen E2, virus yang menyebabkan terekspresinya onkogen virus E6 dan E7. Produk E6 dan E7 menghambat aktivitas tumor supresor p53 dan protein rb (Chakrabarti and Krishna, 2003). P53 berfungsi sebagai faktor transkripsi gen-gen yang terlibat pada fase checkpoint siklus sel dan proses apoptosis. Proliferasi sel yang tidak terkontrol serta penurunan apoptosis merupakan salah satu fungsi seluler yang berubah pada kanker serviks yang diakibatkan degradasi (Borges, et al., 2004).

Pengobatan kanker serviks sering dilakukan dengan berbagai cara, antara lain, operasi atau pembedahan, penyinaran atau radiasi, kemoterapi serta yang sekarang berkembang adalah imunoterapi. Namun, terapi pembedahan tidak dapat dilakukan khususnya pada sel kanker yang telah menyebar, sedangkan kemoterapi dan radiasi juga memiliki beberapa keterbatasan. Kemampuan sinar yang biasa digunakan untuk radiasi mengalami penurunan efektivitas seiring peningkatan ukuran tumor, karena penambahan dosis yang diberikan melebihi batas toksisitasnya pada jaringan dan organ normal manusia. Penggunaan obat kimia seperti kemoterapi mengalami kegagalan untuk menginduksi kematian sel kanker secara terprogram (Pitkin et al., 2003).

Berdasarkan fakta-fakta tersebut pengembangan obat antineoplastik baru menjadi isu kunci dan pilihan strategis untuk menggantikan pengobatan kanker lama atau sebagai usaha meningkatkan sensitivitas modalitas terapi yang telah ada sebelumnya. Salah satu alternatif pengobatan antikanker yang sudah dikembangkan adalah obat herbal (Sudarsono, 2002).

Menurut banyak penelitian golongan senyawa kimia dalam herbal medicine adalah alkaloid, flavonoid, minyak atsiri, dan senyawasenyawa terpen mempunyai potensi antikanker. Senyawa alkaloid mampu mengikat tubulin (protein penyusun mikrotubulus) sehingga dapat menghambat polimerase protein sehingga mengganggu proliferasi sel (Harborne, 2004).

Flavonoid menghambat ekspresi enzim topoisomerase I dan topoisomerase II yang berperan dalam katalisis pemutaran dan relaksasi DNA. Inhibitor enzim topoisomerase akan menstabilkan komplek topoisomerase dan menyebabkan DNA terpotong sehingga mengalami kerusakan. Kerusakan DNA dapat menyebabkan terekspresinya protein proapoptosis seperti Bax dan menurunkan ekspresi protein antiapoptosis yaitu Bcl-2 (Roth, et al., 1986).

Penelitian antikanker telah dilakukan terhadap familia rubiaceae antara lain tanaman sarang semut (Myrmecodia pendans Merr \& Perry), tanaman mengkudu (Morinda citrifolia), Gambir (Uncaria gambir), Biji kopi (Coffea sp.) (Departemen Farmakologi dan Terapeutik, 2007).

Berdasarkan penelitian kandungan senyawa antikanker pada familia rubiaceae adalah tanaman sarang semut (Myrmecodia pendans Merr \& Perry) mengandung senyawa falvonoid, tanin dan tokofenol (Budiani, dkk., 2007). Tanaman mengkudu (Morinda citrifolia) mengandung flavonoid, skopoletin, antrakuinon, dan alkaloid (Hermansyah, dkk., 2010). Gambir (Uncaria gambir) mengandung senyawa flavonoid, dan sejumlah alkaloid (tanin, turunan dihidro-dan oksonya), katekin serta zat penyamak (Fitri, 2008). Biji kopi (Coffea sp.) mengandung senyawa fenolik, flavonoid dan alkaloid (Haquea, et al., 2013).

Penapisan aktivitas senyawa aktif antikanker dapat dilakukan dengan cara kemotaksonomi, yaitu didasarkan pada kemiripan kandungan kimia pada familia atau genus tumbuhan yang sama. Tumbuhan Salung telah dimanfaatkan secara turun temurun untuk mengobati berbagai macam penyakit (Salni, 2009). Tumbuhan salung juga termasuk familia rubiaceae diduga mengandung unsur senyawa yang sama sehingga penelitian ini diajukan untuk mengetahui fraksi-fraksi senyawa antikanker serta efek ekstrak dan fraksi daun salung (Psychotria viridiflora Reinw. Ex. Blume) pada sel kanker serviks HeLa.

\section{METODE PENELITIAN \\ Alat dan Bahan}

Blender, tabung elemeyer, corong, kertas saring, rotary evaporator, gelas ukur, labu pisah $1000 \mathrm{ml}$, penangas air, cawan petri, tiang penyangga, botol, timbangan analitik, plat silica, 
mikropipet 10, 20, 200 dan $1000 \mu 1$, botol duran $100 \mathrm{ml}$, conical tube, pipet pasteur steril atau mikropipet $1000 \mu 1$, tabung reaksi kecil, rak tabung kecil, 96-well plate, 6-well plate, conical tube, dan ELISA reader dengan panjang gelombang $595 \mathrm{Nm}$ dan $550 \mathrm{Nm}$, votex, tabung sentrifus $1,5 \mathrm{ml}$, rak tabung kecil, sentrifugator, inkubator $\mathrm{CO}_{2}$, penangas air $\left(37^{\circ} \mathrm{C}\right)$ dan FACS-Calibur, simplisia dari daun salung, pelarut $n$-heksan, etil asetat dan etanol air, cisplatin, sel HeLa yang merupakan koleksi dari laboratorium parasitologi UGM, FBS (Fetal Bouvin Serum) 10\%, penisilin-streptomisin $1 \%$ fungizone $0,5 \%$, tripsin-EDTA (Ethylenediaminetetraacetic acid) 0,25\%, PBS dan MK (DMEM/RPMI), 3-(4,5-dimetilthiazol-2-il)2,5-difeniltetrazolium bromida (MTT), SDS (Sodium Dodecyl Sulphate) 10\% dalam 0,01 N $\mathrm{HCl}$, stok sampel (10mg) dalam eppendorf, pelarut DMSO, Media Kultur (MK), Phosphat Buffer Saline (PBS), tripsin-EDTA 0,25\%, RNase, Propidium iodide, Triton- $X$, buangan untuk media bekas dan PBS.

\section{Jalannya Penelitian}

\section{Ekstraksi dan Fraksinasi}

Ekstraksi dan fraksinasi simplisia daun salung dilakukan di Laboratorium Kampus Biologi UNSRI Palembang.

\section{Penentuan Golongan Senyawa}

Golongan senyawa yang terdapat dalam fraksi akan ditentukan dengan uji KLT. Prosedur uji KLT yang dilakukan dengan cara, ekstrak, fraksi n-heksan, fraksi etil asetat dan fraksi etanol air dengan konsetrasi $1 \%$ ditotolkan pada plat silika gel $\mathrm{F}_{254}$ ukuran $1 \mathrm{~cm} \times 6 \mathrm{~cm}$, kemudian dikembangkan dengan eluen (pelarut n-heksan sebanyak $8 \mathrm{ml}$ dicampur dengan pelarut etil asetat sebanyak $2 \mathrm{ml}$ ), biarkan hingga eluen sampai diujung plat silika gel $\mathrm{F}_{254}$ lalu dikeluarkan dan biarkan mengering. Plat silikagel F254 disemprotkan dengan larutan $\mathrm{H}_{2} \mathrm{SO}_{4} \quad 1 \%$ lalu diletakkan diatas hot plate. Diamati bercak warna yang muncul.

\section{Preparat dan Panen Sel}

Sel diambil dari tangki nitrogen cair, kemudian dicairkan dalam penangas air $37^{\circ} \mathrm{C}$. Setelah itu disemprotkan dengan etanol $70 \%$, sel dalam cryotube dimasukkan ke dalam LAF dan dipindahkan dengan menggunakan mikropipet ke dalam tabung conikel yang berisi suspensi sel disentrifuge pada $600 \mathrm{rpm}$ selama 5 menit, lalu supernatan dibuang. Selanjutnya ditambahkan media yang baru kedalam konikel yang berisi pelet dan disuspensikan hingga homogen. Suspensi sel ditumbuhkan dalam tissue culture dish yang diinkubasi dalam inkubator $\mathrm{CO}_{2} 5 \%$ dengan suhu $37^{\circ} \mathrm{C}$. Kondisi sel selanjutnya diamati dibawah mikroskop kemudian diinkubasi pada inkubator $\mathrm{CO}_{2} 5 \%$. Setelah 24 jam dilakukan penggantian media kultur. Sel ditumbuhkan sampai konfulen dan jumlahnya cukup untuk perlakuan. Setelah konfulen dilakukan panen sel dengan cara membuang media kultur lalu dicuci dengan PBS $2 \mathrm{x}$ untuk melepas sel dari dasar culture dish ditambahkan tripsin-EDTA $0,25 \%$ kemudian diinkubasi selama 3 menit dalam inkubator $\mathrm{CO}_{2}$, Tripsin-EDTA diinaktivasi dengan menambahkan media kultur kemudian suspensi sel diresuspensi lalu suspensi dipindahkan pada conical tube. Jumlah sel dihitung dengan menggunakan hemocytometer dan cell counter. Rumus Perhitungan sel HeLa yaitu:

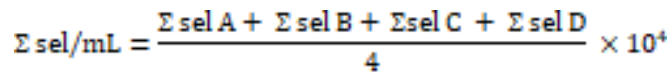

\section{Pembuatan Larutan Stok Uji Ekstrak dan Fraksi}

Sebelum dilakukan uji sitotoksik, terlebih dahulu dibuat larutan stok sampel dengan cara mencampur ekstrak etanol, fraksi etil asetat, fraksi n-heksan dan fraksi etanol air dari daun salung ((Psychotria viridiflora Reinw. Ex. Blume) dengan media DMEM (Dulbecco's Modification of Eagle Medium). Larutan stok dibuat dengan cara menimbang ekstrak etanol, fraksi etil asetat, fraksi n-heksan dan fraksi etanol air dari daun salung ((Psychotria viridiflora Reinw. Ex. Blume) kemudian ditambah DMSO atau tween sebanyak $30 \mu 1$ dan ditambahkan dengan media DMEM hingga $1000 \mu 1$, sehingga diperoleh konsentrasi tertentu. Dari konsentrasi larutan tersebut kemudian dibuat seri kadar dan larutan dalam berbagai kadar tersebut dapat diujikan di dalam Laminar Air Flow Cabinet secara aseptis (Utami, 2011).

\section{Uji Sitotoksisitas}

Dari uji ini dapat diperoleh kadar yang menyebabkan penghambatan pertumbuhan sel sebesar $50 \%$ dari populasi sel atau $\mathrm{IC}_{50}$ yang merupakan parameter ketoksikan sehingga dapat diketahui kisaran kadar yang berefek toksik terhadap sel kanker.

Uji sitotoksisitas ini dilakukan dengan metode MMT assay. Sebelum dilakukan uji sitotoksisitas terlebih dahulu dilakukan preparasi dan panen sel. Jumlah sel dihitung dengan menggunakan hemocytometry. 
Setelah panen sel dibuat larutan stok sampel sehingga diperoleh konsentrasi $320 ; 160 ; 80 ; 40$ $\mu \mathrm{l} / \mathrm{ml}$ untuk ekstrak etanol dan fraksi etil asetat, etanol air, serta n-heksan. Cisplatin diencerkan dengan DMEM sehingga diperoleh konsentrasi 200, 100, 50, $25 \mu \mathrm{l} / \mathrm{ml}$.

Selanjutnya sel diberi perlakuan ekstrak dan fraksi, setelah itu diinkubasi dalam inkubator $\mathrm{CO}_{2}$ selama 24 jam, kemudian tiap sumuran diberi larutan MTT sejumlah $10 \mu 1$, empat jam kemudian dilanjutkan dengan pemberian reagen stopper (SDS $10 \%$ dalam HCL $0,01 \quad \mathrm{~N})$. Kemudian plate dibungkus dengan kertas atau alumunium foil dan inkubasikan ditempat gelap pada temperatur kamar selama semalam. Setelah 24 jam plate dimasukkan ke dalam ELISA reader Baca absorbansi masingmasing sumuran dengan panjang gelombang 550 nm. Pengukuran dilakukan pada panjang gelombang $550 \mathrm{~nm}$, yaitu panjang gelombang optimum agar diperoleh pengukuran yang peka dan spesifik (CCRC, 2009).

Data dari uji sitotoksisitas digunakan untuk menghitung kadar yang menyebabkan hambatan proliferasi sel $50 \%\left(\mathrm{IC}_{50}\right)$ dengan anlisa probit. Persentase sel hidup setelah perlakuan pada masing-masing kadar dihitung dengan rumus:

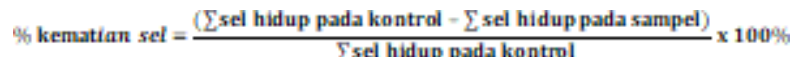

Setelah didapatkan \% kematian sel pada masing-masing konsentrasi bahan uji, maka langkah selanjutnya adalah menentukan nilai $\mathrm{IC}_{50}$ dengan menggunakan metode regresi linear untuk mendapatkan linearitas antara kadar konsentrasi dengan persen kematian sel. $\mathrm{IC}_{50}$ adalah konsentrasi yang menyebabkan kematian 50\% populasi sel, sehingga dapat diketahui potensi sitotoksisitasnya. Uji sitotoksik ini digunakan untuk menentukan nilai $\mathrm{IC}_{50}$. Nilai $\mathrm{IC}_{50}$ menunjukkan nilai kadar konsentrasi yang menghasilkan hambatan proliferasi sel $50 \%$ dan menunjukkan potensi ketoksikan suatu senyawa terhadap sel. Nilai ini merupakan patokan untuk melakukan uji pengamatan kinetika sel. Nilai $\mathrm{IC}_{50}$ menunjukkan potensi suatu senyawa sebagai bahan toksik, semakin besar harga $\mathrm{IC}_{50}$ maka senyawa tersebut semakin tidak toksik (Anggraini, 2008).

\section{Analisis Data}

Uji sitotoksik diperoleh dari hasil pembacaan absorbansi dengan menggunakan ELISA reader pada setiap sumuran yang kemudian dikonvensi dalam persen sel hidup (viabilitas sel) dengan menggunakan Microsoft excel 2007. Pada uji sitotoksik, presentase sel yang hidup digunakan untuk menentukan nilai $\mathrm{IC}_{50}$ merupakan konsentrasi yang dapat menyebabkan penghambatan pertumbuhan sel banyak $50 \%$ dari populasi sel. Dalam menentukan nilai $\mathrm{IC}_{50}$ menggunakan dengan Microsoft Excell 2007 (Regresi linear dari \% kematian sel dan kadar konsentrasi perlakuan). Data persen kematian sel ditampilkan dalam bentuk grafik garis. Nilai $\mathrm{IC}_{50}$ diperoleh dengan mengganti nilai $\mathrm{y}=50$ (Ghosal and Mandal, 2012).

\section{HASIL DAN PEMBAHASAN}

\section{Ekstraksi dan Fraksinasi daun salung ((Psychotria viridiflora Reinw. Ex. Blume)}

Pada hasil penelitian ini dapat dilihat bahwa dari 250 gram simplisia daun salung dihasilkan sebanyak 45,7 gram ekstrak yakni 18,28\% dari jumlah simplisia. Kandungan ekstrak dalam simplisia berbeda-beda tergantung pada jumlah senyawa organik didalamnya. Sisa hasil ekstrak kental daun salung 31,8 gram dilanjutkan untuk pengujian fraksinasi dengan metode FCC (Fraksi Cair-Cair) dengan pelarut n-heksan, etil asetat dan methanol air secara kesinambungan dengan sifat kepolaran pelarut yang berbeda-beda. Berat fraksi yang diperoleh dapat dilihat pada tabel 1 dibawah ini:

Tabel 1 Hasil Fraksinasi daun salung ((Psychotria viridiflora Reinw. Ex. Blume)

\begin{tabular}{lcc}
\hline \multicolumn{1}{c}{ Pelarut } & Berat (gram) & $\begin{array}{c}\text { Persentase } \\
(\mathbf{\%})\end{array}$ \\
\hline Fraksi n- & 4,7 & 14,8 \\
heksan & 8,4 & 26,4 \\
Fraksi etil & 18,7 & 58,8 \\
asetat & & \\
Fraksi & & \\
metanol air & & $\mathbf{1 0 0}$ \\
\hline \multicolumn{1}{c}{ Total } & $\mathbf{3 1 , 8}$ & \\
\hline
\end{tabular}

Dari Tabel 1 dapat dilihat hasil fraksinasi ekstrak daun salung (Psychotria viridiflora Reinw. Ex. Blume) yang memiliki berat lebih besar pada fraksi methanol air dibandingkan dengan fraksi nheksan dan etil asetat. Hal tersebut dikarenakan pelarut methanol air mempunyai kemampuan dalam menarik dan memisahkan senyawa kimia yang bersifat polar (Holetz, 2002). Berat fraksi yang didapatkan berbeda-beda tergantung dari pelarut yang digunakan, namun besar kecilnya kemampuan sitotoksik suatu fraksi tidak dipengaruhi oleh berat fraksi, kemudian ekstrak dan ketiga macam fraksi yang diperoleh di uji 
aktivitas antikankernya terhadap sel HeLa dengan metode MTT assay.

\section{Penentuan Golongan Senyawa}

Untuk menentukan golongan senyawa yang terdapat dalam ekstrak dan fraksi daun salung menggunakan metode Kromatografi Lapis Tipis (KLT) yaitu mengamati bercak warna yang muncul.

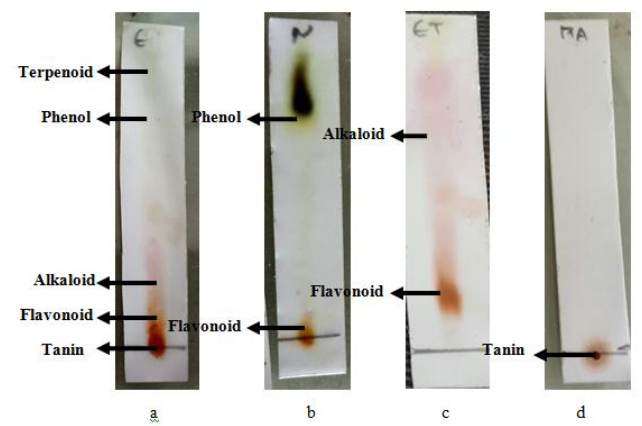

Gambar 1 Uji KLT daun salung (a) ekstrak (b) fraksi n-heksan (c) fraksi etil asetat (d) fraksi methanol air.

Berdasarkan Gambar 1 maka hasil uji KLT golongan senyawa ekstrak dan fraksi daun salung dapat dilihat pada tabel 2 dibawah ini:

Tabel 2 Hasil Uji KLT Ekstrak dan Fraksi Daun Salung (Psychotria viridiflora Reinw. Ex. Blume)

\begin{tabular}{|c|c|c|}
\hline Bahan Uji & $\begin{array}{l}\text { Warna } \\
\text { Bercak }\end{array}$ & $\begin{array}{c}\text { Golongan } \\
\text { Senyawa }\end{array}$ \\
\hline $\begin{array}{l}\text { Ekstrak } \\
\text { etanol }\end{array}$ & $\begin{array}{l}\text { ungu, coklat, } \\
\text { merah muda, } \\
\text { orange, } \\
\text { kuning }\end{array}$ & $\begin{array}{l}\text { Terpenoid, } \\
\text { alkaloid, } \\
\text { flavonoid, } \\
\text { tanin, Phenol }\end{array}$ \\
\hline $\begin{array}{l}\text { Fraksi n- } \\
\text { heksan }\end{array}$ & $\begin{array}{l}\text { Orange, } \\
\text { kuning }\end{array}$ & $\begin{array}{l}\text { Flavonoid, } \\
\text { Phenol }\end{array}$ \\
\hline $\begin{array}{l}\text { Fraksi etil } \\
\text { asetat }\end{array}$ & $\begin{array}{l}\text { Merah muda, } \\
\text { coklat }\end{array}$ & $\begin{array}{l}\text { Alkaloid, } \\
\text { flavonoid }\end{array}$ \\
\hline $\begin{array}{l}\text { Fraksi } \\
\text { methanol air }\end{array}$ & Coklat & Tanin \\
\hline
\end{tabular}

Dalam uji KLT diatas menunjukkan bahwa pada ekstrak etanol mengandung tanin, flavonoid dan tanin. Setelah dilakukan proses fraksinasi, didapatkan fraksi n-heksan yang mengandung tanin dan terpenoid, fraksi etil asetat mengandung flavonoid dan fraksi metanol air mengandung tanin.

\section{Uji Sitotoksik}

Uji sitotoksik digunakan untuk memprediksi keberadaan obat sitotoksik baru dari

bahan alam yang berpotensi sebagai antikanker Prosedur uji sitotoksik dengan uji MTT menurut CCRC (2009). Hasil inkubasi sel dengan MTT selanjutnya akan dibaca intensitas warna ungunya sebagai penanda sel hidup dengan menggunakan ELISA reader dengan panjang gelombang $595 \mathrm{~nm}$. Hasil pembacaan ELISA reader akan menghasilkan nilai absorbansi dari enam ulangan pada masing-masing konsentrasi dan nilai rata-rata persentase kematian sel HeLa setelah diberi perlakuan. Hasil uji sitotoksik dari ekstrak dan fraksi daun salung dapat dilihat pada tabel 3 dibawah ini:

Tabel 3 Hasil Rata-Rata Absorbansi dan Hasil Persen Kematian Sel HeLa

\begin{tabular}{lrccc}
\hline Konsentrasi Bahan Uji $(\mu \mathrm{g} / \mathrm{ml})$ & $\begin{array}{c}\text { Rata-Rata } \\
\text { Absorbansi }\end{array}$ & $\begin{array}{c}(\%) \text { Kematian } \\
\text { Sel HeLa }\end{array}$ & $\begin{array}{c}\text { Nilai IC } \\
(\mu \mathrm{g} / \mathrm{ml})\end{array}$ \\
\hline Ekstrak etanol & 640 & 0,316 & 60,721 & 380,7 \\
& 320 & 0,411 & 48,912 & \\
& 160 & 0,436 & 45,805 & \\
& 80 & 0,512 & 36,358 & \\
& 40 & 0,572 & 28,899 & \\
\hline Fraksin-heksan & 640 & 0,267 & 66,812 & \\
& 320 & 0,321 & 60,099 & 229,3 \\
& 160 & 0,440 & 45,308 & \\
& 80 & 0,468 & 41,827 & \\
& 40 & 0,477 & 40,709 & \\
\hline Fraksi etil asetat & 640 & 0,238 & 70,416 & \\
& 320 & 0,329 & 59,105 & \\
& 160 & 0,354 & 55,997 & 116,8 \\
& 80 & 0,421 & 47,669 & \\
\hline Fraksi methanol air & 60 & 0,449 & 44,189 & \\
& 640 & 0,386 & 52,019 & 562,8 \\
& 320 & 0,465 & 42,200 & \\
& 160 & 0,534 & 33,623 & \\
& 80 & 0,561 & 30,267 & \\
\hline Cisplatin & 40 & 0,640 & 20,447 & \\
& 200 & 0,226 & 71,908 & \\
& 100 & 0,319 & 60,316 & \multirow{2}{*}{. } \\
& 50 & 0,378 & 53,014 & 47,2 \\
\hline
\end{tabular}

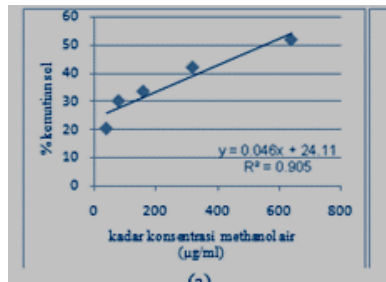

(a)

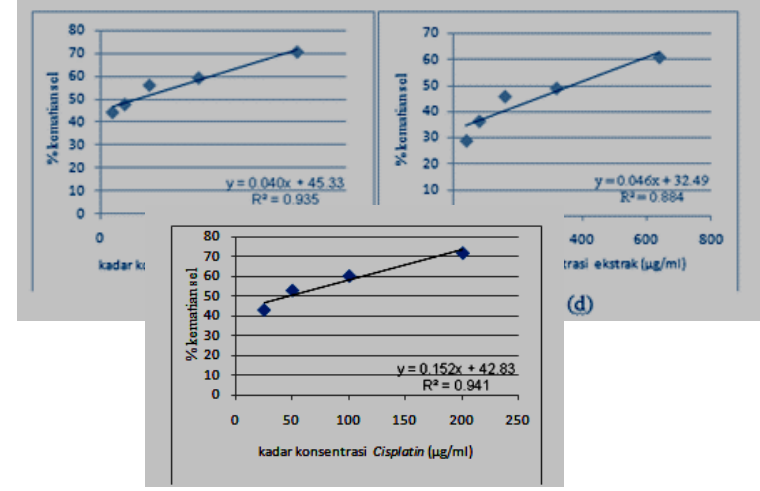

Gambar 2 Grafik persamaan regresi linear antara \% kematian sel dan kadar konsentrasi.

Keterangan: (a) Fraksi methanol air (c) Fraksi etil asetat (e) Cisplatin $\begin{array}{ll}\text { (b) Fraksin-heksan } & \text { (d) Ekstrak }\end{array}$

linear diperoleh nila1 $Y=0,046 X+32,49$ untuk ekstrak etanol, nilai $\mathrm{Y}=0,046 \mathrm{X}+39,45$ untuk 
fraksi $\mathrm{n}$-heksan, nilai $\mathrm{Y}=0,040 \mathrm{X}+45,33$ untuk fraksi etil asetat, nilai $\mathrm{Y}=0,046 \mathrm{X}+24,11$ untuk fraksi methanol air dan $\mathrm{Y}=0,152 \mathrm{X}+42,83$ untuk cisplatin.

Menurut Tabel 2 diketahui bahwa ekstrak dan fraksi daun salung mempunyai aktivitas antikanker cukup aktif terhadap sel HeLa. Klasifikasi aktivitas sitotoksik ekstrak terhadap sel kanker dapat digolongkan kategori sangat aktif jika nilai $\mathrm{IC}_{50}<10 \mu \mathrm{g} / \mathrm{ml}$, kategori aktif jika nilai $\mathrm{IC}_{50}$ $10-100 \mu \mathrm{g} / \mathrm{ml}$, dan kategori cukup aktif jika nilai $\mathrm{IC}_{50} 100-500 \mu \mathrm{g} / \mathrm{ml}$ (Weerapreeyakul, et al., 2012). Dari keempatnya nilai $\mathrm{IC}_{50}$ tertinggi diberikan oleh fraksi methanol air daun salung yaitu $562,8 \mu \mathrm{g} / \mathrm{ml}$, hal ini menunjukkan bahwa fraksi methanol air mempunyai aktifitas sitotoksik sangat rendah, dimana sel baru dapat di hambat $50 \%$ pada konsentrasi $562,8 \mu \mathrm{g} / \mathrm{ml}$, sedangkan nilai $\mathrm{IC}_{50}$ terendah terdapat pada fraksi etil asetat dengan nilai $\mathrm{IC}_{50} 116,8 \mu \mathrm{g} / \mathrm{ml}$ sehingga dapat disimpulkan bahwa fraksi etil asetat cukup aktif dibandingkan dengan fraksi n-heksan, ekstrak dan fraksi methanol air sebagai senyawa antikanker pada sel HeLa. Hal ini mengidentifikasi bahwa keberadaan senyawa aktif yang mempunyai efek sitotoksik pada fraksi etil asetat.

Pada kelompok kontrol positif (cisplatin) nilai $\mathrm{IC}_{50}$ yang dihasilkan sangat rendah yaitu 47,2 $\mu \mathrm{g} / \mathrm{ml}$ sehingga jauh lebih toksik dari ekstrak dan fraksi daun salung walaupun cisplatin merupakan obat sitotoksik dengan efektifitas tinggi dan digunakan secara luas namun efek samping penggunaannya juga tinggi. Berdasarkan penelitian Nissa, dkk (2015) menyatakan efek samping cisplatin adalah nefrotoksisitas dimana persentase kejadian sebesar 20-30\% dan menurut Kurniandari (2015) menyatakan berbagai efek samping yang mungkin terjadi pada penggunaan cisplatin adalah ototoksisitas, gastrotoksisitas, supresi sumsum tulang reaksi alergi dan nefrotoksisitas.

Belum ada publikasi yang melaporkan mengenai aktivitas antikanker dari ekstrak dan fraksi daun salung (Psychotria viridiflora) namun berdasarkan penelitian sebelumnya pada tumbuhan sefamilia rubiaccae yaitu menurut Yulia (2009) tentang fraksinasi daun mengkudu menunjukkan adanya kenaikkan persen kematian sel alami (apoptosis) seiring dengan kenaikkan kadar protein terhadap sel kanker serviks HeLa dengan nilai $\mathrm{IC}_{50}$ yang rendah yaitu $6,9 \mu \mathrm{g} / \mathrm{ml}$ dan menurut Febriansah (2010) tentang ekstrak etanol buah mengkudu memiliki potensi sebagai agen kemopreventif melalui mekanisme sitotoksik terhadap sel kanker serviks HeLa dengan nilai $\mathrm{IC}_{50}$ yaitu $4.094 \mu \mathrm{g} / \mathrm{ml}$, serta penelitian Meyer, et.al (1982) menyatakan fraksi etil asetat dari tanaman sarang semut memiliki nilai $\mathrm{LC}_{50}$ sebesar 938,003 $\mu \mathrm{g} / \mathrm{ml}$ menunjukkan bahwa fraksi ini mempunyai aktivitas sitotoksik terhadap sel kanker.

Berdasarkan nilai $\mathrm{IC}_{50}$ yang di dapat pada penelitian ini bahwa pada fraksi etil asetat nilai $\mathrm{IC}_{50}$ sebesar $116,8 \mu \mathrm{g} / \mathrm{ml}$ lebih kecil dari fraksi yang lain dan ekstrak sehingga fraksi etil asetat merupakan fraksi aktif .

\section{KESIMPULAN}

1. Nilai $\mathrm{IC}_{50}$ ekstrak daun salung (Psychotria viridiflora Reinw. Ex. Blume) terhadap sel $\mathrm{HeLa}$ adalah 380,7 $\mu \mathrm{g} / \mathrm{ml}$, fraksi n-heksan sebesar $229,3 \mu \mathrm{g} / \mathrm{ml}$, fraksi etil asetat sebesar $116,8 \mu \mathrm{g} / \mathrm{ml}$, dan fraksi methanol air sebesar $562,8 \mu \mathrm{g} / \mathrm{ml}$, sehingga fraksi etil asetat mempunyai aktivitas sitotoksik kategori cukup aktif dilihat dari nilai $\mathrm{IC}_{50}$.

2. Golongan senyawa yang terdapat dalam fraksi aktif etil asetat adalah alkaloid dan flavonoid.

\section{SARAN}

1. Perlu dilakukan pengujian lebih lanjut dengan sel vero (sel normal) dengan berbagai konsentrasi agar didapatkan nilai $\mathrm{IC}_{50}$ bahan uji terhadap sel normal.

2. Perlu dilakukan penelitian lebih lanjut sampai didapatkan senyawa murni dan identifikasi struktur senyawa yang memiliki aktvitas sebagai antikanker dari fraksi daun salung.

\section{DAFTAR PUSTAKA}

Adriyani. 2012. Struktur Senyawa Alkaloid. http://pharmaxchange.info/press/2012/07/classi fication-of-alkaloids/. Diakses Januari 2017.

Agarwal, P., Fatima A., Alok S., Singh P., and Verma A., 2013. An Update on Disease Profile of Cancer with Herbal Treatment. IJPSR.

Aguilan, J. T. 2003. Structural Analysis of Carrageenan from Farmed Varieties of Philippine Seaweed, De Gruyter Journal. Berlin.

Anggraini, P. 2008. Uji Sitotoksik Ekstrak Etanol 70\% Buah Kumukus (Piper Cubeba L) terhadap Sel HeLa. Fakultas Farmasi Universitas Muhammadiyah Surakarta. 
CCRC. 2009. Standart Operating Procedure Cancer Chemoprevention Research Center. Fakultas Farmasi UGM Yogyakarta.

Departemen Farmakologi dan Terapeutik. 2007. Farmakologi dan Terapi Edisi V. Jakarta: Fakultas Kedokteran.

Devita, Heilman and Rosenberg's. 2008. Cancer: Principles and of Ancology. ${ }^{\text {th }}$ Edition.

Febriansah R. 2010. Kajian Secara In Vitro Ekstrak Etanolik Buah Mrinda Citrifolia L. sebagai Agen Khemopreventif Kanker Payudara yang Potensial. Magister Tesis. Fakultas Kedokteran dan Ilmu Kesehatan Universitas Muhammadiyah. Yogyakarta.

Fitri, Dini Mai. 2008. Uji Aktivitas Antiproliferasi Senyawa (+)-2-2'-Episitoskirin A dari Jamur Endofit Diaporthe Sp. yang Diisolasi dari Tumbuhan Gambir (Uncaria Gambier Roxb) terhadap Beberapa Sel Kanker. Magister Tesis. Fakultas MIPA.

Freshney, R.I., 2005, Animal Cell Culture a Practical Approach, ed. 5, IRL Press, Washington DC.

Guillemin, Roger. 2006. Struktur Senyawa Flavonoid.

http://www.pnas.org/content/103/44/16568.fig ures-only. Diakses Januari 2017.

Heim KE, Tagliaferro AR, Bobilya DJ. 2002 Flavonoid Antioxidants: Chemistry, Metabolism and Structure-Activity Relationships. Biochemistry.

Hermansyah, Herlina, Sugiyama M, Harashima S. 2010. Yeast Saccharomyces Cerevisiae as Model to Identify Mengkudu (Morinda Citrifolia) as an Anticancer Medicinal Plants Candidates with Antiproliferative Properties. Palembang: Chemistry Department, Faculty Of Mathematics and Naturalsciences, Sriwijaya University.

Hernani. 1999. Teknik Identifikasi Bahan Aktif pada Tumbuhan Obat. Makalah pada Seminar Pendalaman Materi di Balai Penelitian Tanaman Rempah dan Obat. Bogor.

King RJ, Robins MW. 2006. Cancer Biology, $3^{\text {rd }}$ ed. England: Pearson Education Limited.
Kurniandari, N., Susantiningsih, T., dan Berawi, K. N., 2015. Efek Ekstrak Etanol Kulit Jeruk Nipis (Citrus Aurantifolia) Sebagai Senyawa Nefroprotektor terhadap Gambaran Histopatologis Ginjal yang di Induksi Cisplatin. Majority.

Lalitha, S., Parthipan, B., Mohan, V. 2015. Penentuan Bioaktif Komponen Nilgiriensis Deb dan Gang (Rubiaceae) dengan GC-MS Analisis. Journal of Farmakognosi dan Fitokimia. India.

Lisdawati V. 2002. Mahkota Dewa, Toksisitas, Efek Antioksidan, dan Efek Antikanker Berdasarkan Uji Penapisan Farmakologi. Jakarta: PT Phaleria Macrocarpa.

Malole, MBM. 1990. Kultur Sel dan Jaringan Hewan. Bogor: Institut Pertanian Bogor.

Manuaba, IBG, dkk. 2009. Gawat Darurat Obstetri-Ginekologi dan Obstetri-Ginekologi Sosial untuk Profesi Bidan. Jakarta: EGC.

Natanel, Andry. 2014. Struktur Senyawa Tanin. Http://mahasiswafarmasibicara.blogspot.co.id /2014/06/sifat-dan-manfaat-tanin.html. Diakses Januari 2017.

Robinson, T. 1998. Kandungan Organik Tumbuhan Tinggi, Terjemahan oleh Kosasih Padmawinata, Edisi 6. ITB: Bandung.

Salni. 2003. Karakterisasi dan Uji Aktivitas Topical Senyawa Antibakteri dari Daun Karamunting \{Rhodormyrtus Tomentosa (Ait.) Hassk\} dan Uji Efektivitas Sediaan Salepnya. Disertasi. ITB. Bandung.

Salni. 2009. Eksplorasi Bahan Bioaktif Antibakteri untuk Mengobati Infeksi Penyakit Kulit di Sumatera Selatan. Lembaga Penelitian Unsri. Indralaya.

Saphiro, Geoffrey I, dan Harper, J, Wade. 1999. Anticancer Drug Targets: Cell Cycle and Checkpoint Control, J. Clin Invest.

Setyawati, yunita. 2014. Sitotoksisitas dan Apoptosis Ekstrak Daun Jeruk Purut (Citrus Hystrix D.C.) terhadap Sel Hela (Human Cervical Cancer Cell Line). Skripsi. Fakultas Biologi Universitas Gajah Mada. Yogyakarta.

Sinta, Novel S. dkk. 2010. Kanker Serviks dan Infeksi Human Pappiloma Virus 
(HPV). (http://dr-

suparyanto.blogspot.com/2011/04/kanker-

leher-rahim-carsinoma-cervix.html). Di akses pada November 2016.

Sirait, M. 2007. Penuntun Fitokimia dalam Farmasi. ITB. Bandung.

Siswandono dan Soekarjo, B. 2000. Kimia Medicinal Edisi II. Surabaya: Universitas Airlangga Press.

Sudarsono. 2002. Tumbuhan Obat II. Yogyakarta: Pusat Studio Obat Tradisional Universitas Gadjah Mada.

Utami, Dewi., 2011. Aktivitas Sitotoksik Isolat 5 Fraksi Etil Asetat Ekstrak Petroleum Eter Daun Phaleria Macrocarpa (Scheff) Boerl pada Turunan Sel Kanker Serviks Manusia (HeLa). Jurnal Ilmiah Kefarmasian, 1.

Walin, R.F. 1998. A Practical Guide to ISO: Cytotoxicity, An MD And DI.

Widyastuti, Yani. 2009. Kesehatan Reproduksi. Yogyakarta: Fitramaya.

Wiknjosastro, Hanifah. 2006. Ilmu Kebidanan. Jakarta: Yayasan Bina Pustaka Sarwono Prawirohardjo

Williams, FG. 2008. Human Papilloma Virus and Human Immune Deficiency Virus-Infeted Women.

Wulansari HN, Sejati AA, Supriatno, Indrayanti. 2010. Efektivitas Ekstrak Etanol Tanaman Sarang Semut terhadap Proliferasi Sel Kanker Lidah Manusia (SP-C1) In Vitro Experimental Study. Prosiding Seminar Ilmiah Kesehatan. Yogyakarta. 
